\title{
Effects of Running Shoes with Abrasion Resistant Rubber Sole on the Exercise Capacity of the Human Body
}

DOI: $10.15255 /$ KUI.2017.024

KUI-38/2017

Professional paper

Received June 14, 2017

Accepted September 1, 2017

This work is licensed under Creative Commons Attribution 4.0

\author{
B. Wang* \\ College of Physical Education, Sichuan Normal University, \\ Chengdu, Sichuan 610 101, P.R. China
}

\begin{abstract}
\| Abstract
With the development of industrialization, rubber has been gradually used in the manufacture of sports equipment for its favourable properties. This study involved the addition of $\mathrm{C} 5$ petroleum resin into brominated isobutylene-isoprene rubber (BIIR) and butadiene rubber (BR) while manufacturing the sole of running shoes. The effects of running shoes with abrasion resistant rubber sole on the exercise capacity of the human body were investigated by analysing the skid resistance and abrasion resistance of the running shoes, and conducting biomechanical study on naked feet and feet wearing the shoes. The results demonstrated that the rubber sole had favourable slip resistance property and mechanical properties such as stretching, abrasion resistance, and hardness. Compared to naked feet, the peak pressure intensity of the whole step of feet wearing the newly developed shoes, was significantly lower than that of feet wearing ordinary shoes. In the future, rubber can bring more comfortable experience because of its favourable properties.
\end{abstract}

\section{\| Keywords}

Rubber shoes, performance analysis of rubber sole, biomechanics

\section{Introduction}

With the development of social economy, the requirements for comfortable, and slip- and abrasion-resistant footwear has become increasingly higher. Rubber has been applied gradually in the field of sports equipment, especially in the design of running shoes because of its favourable performance. K. Pyo et al. mixed butadiene rubber with isobutyl rubber to improve abrasion and then used it in the manufacture of the sole. ${ }^{1}$ Moreover, an experiment was carried out to prove that the compound rubber, composed of $60 \%$ of butadiene rubber and $40 \%$ of isobutyl rubber, could greatly improve the abrasion resistance of the sole.

Y. Wang et al. proposed to manufacture a sole with regenerated rubber microcellular foaming material, and verified the feasibility of the manufacturing method through experiments. ${ }^{2}$ This study involves the manufacture of the sole of running shoes by adding $\mathrm{C} 5$ petroleum resin to brominated isobutylene-isoprene rubber (BIIR) and butadiene rubber (BR), and then analysing the slip and abrasion resistance of the shoes. Through analysing the biomechanics of feet while wearing the running shoes, this study found that the peak pressure of feet wearing the running shoes was much higher than that of naked feet. With the development of science and technology, rubber with favourable properties has been frequently applied in the design of running shoes, allowing a more comfortable experience to the human body.

* Corresponding author: Bo Wang, B. A.

e-mail:wnbo_123@sina.com

\section{Introduction of materials}

\subsection{BIIR}

BIIR is a bromination product generated on double-bond carbon or methyl carbon from butyl rubber, but bromination reaction mainly occurs on a small amount of double-bond carbon or methyl carbon next to double bond in methyl rubber. Therefore, the content of bromine is low in BIIR, and the mass fraction is only $1 \%-2.5 \%{ }^{3}$ As the structure of butyl rubber had no changes and few hydrogen atoms were brominated, BIIR maintained the characteristics of aging resistance, strong barrier and strong heat resistance. ${ }^{4}$ Moreover, BIIR has the characteristics, which butyl rubber does not have, such as fast vulcanization speed and multiple vulcanization modes. BIIR has been extensively applied in various fields, and studies on the processing of BIIR are constantly expanding.

BR is a synthesized rubber with a regular structure, which is produced from the polymerization of butadiene, and its cis-structure content is higher than $95 \%$. Compared to natural rubber, BR has significantly improved cold- and abrasion-resistance properties after vulcanization. ${ }^{5} \mathrm{Moreo}-$ ver, BR has advantages such as good elasticity, favourable rolling resistance, low hysteresis loss and low heat generation rate and can be mixed with multiple rubbers such as natural rubber; hence it can be applied for manufacturing tyres, rubber shoes, and rubberized fabric. ${ }^{6}$

C5 petroleum resin has favourable resistance to heat, water, acid and base. Its tackifying effect is stronger than C9 resin. Moreover, it is highly compatible with natural rubber and synthetic rubber. It can be used as pressure-sensitive adhesive and rubber adhesive. ${ }^{7}$ 
With the development of industry, rubber materials have been gradually applied in running shoes and studies on rubber running shoes are constantly expanding. N. J. Mills found that the design of even appearance could provide a buffer for feet and the shoes made of rubber were more durable. ${ }^{8}$ Through investigating the buffer, tractive force and flexibility of running shoes, $K$. Harano found that the running shoes made of rubber could improve the comfort of running shoes and athletic ability of the human body by effectively enhancing those characteristics.

\subsection{Manufacture of running shoes sole and experimental methods}

The materials included BIIR (Chengdu Xinlongda Rubber Products Co., Ltd., China), BR (Chengdu Xinlongda Rubber Products Co., Ltd., China), C5 petroleum resin (Chengdu Tianli Hongyuan Chemical Co., Ltd., China), white carbon black $^{10}$ (Chengdu Runze Bentu Chemical Co., Ltd., China), accelerant (Chengdu Hanhua New Material Science and Technology Co., Ltd., China), zinc oxide (Chengdu Runze Bentu Chemical Co., Ltd., China), paraffin oil (Chengdu Xinhua Petroleum and Chemical (Commercial) Co., Ltd., China) and sulphur (Chengdu Xinhua Petroleum and Chemical (Commercial) Co., Ltd., China).

The manufacturing tools included twin-roll mixing mill (XK-450, Qingdao Qingxiang Mechanical Co., Ltd., China), vulkameter (CL-2000E, Yangzhou Jingzhuo Testing Machinery Factory, China), Mooney viscometer (JZ-6028, Yangzhou Jingzhuo Testing Machinery Factory, China), dynamic thermomechanical analysis apparatus (DMA-8000, Perkin Elmer Co., Ltd., USA), plate vulcanizer (SY-6210-A, Dongguan Shiyan Precise Instrument Co., Ltd., China), hardness tester (HRD-150T, Shanghai Jujing Precise Instrument Manufacture Co., Ltd., China), electric tension tester (TFW-5S, Shanghai Tuofeng Instrument Science and Technology Co., Ltd., China), abrasion machine (H-X626, Yangzhou Huahui Detection Instrument Co., Ltd., China), impact elasticity tester (CMT1000, Zhuhai Sansi Taijie Electrical Equipment Co., Ltd., China), and slip tester (QI-009, Dongguan Houjie Kailan Detection Instrument Factory, China).

\section{Manufacturing process was as follows:}

(1) BIIR and BR were mixed in a ratio of 3:7 after five mill runs.

(2) C5 was added, followed by white carbon black.

(3) After five minutes of mixing, accelerant and compounding agents such as zinc oxide were added.

(4) After mixing, paraffin oil and sulphur were added.

(5) The rubber was covered along the opposite direction of roller motion five times and processed by sheeting.

(6) After material configuration, it was put aside for $24 \mathrm{~h}$.

(7) The vulcanization and Mooney viscosity of the material were tested using the vulkameter and Mooney viscometer.
(8) It was vulcanized by the plate vulcanizer according to the test results.

After the manufacture of the sample, a performance test was performed to determine whether the sample is qualified for the sole of running shoes.

(1) The sulphuration of the sample was tested on an M-2000-FA vulkameter at a temperature of $150{ }^{\circ} \mathrm{C}$ according to AMD5289-95 standard.

(2) Mooney viscosity test was performed on a GT-7080S2 Mooney viscometer according to ASTMD1646-99 standard. It was preheated by a small rotor at $100{ }^{\circ} \mathrm{C}$ for $1 \mathrm{~min}$, and the test lasted $4 \mathrm{~min}$.

(3) The hardness of the sample was tested using a hardness tester according to ASTMD2240:2005 standard.

(4) Tensile strength and tearing strength were tested using an electronic tensile machine according to ASTMD412:1998 and TSAMD642:2000 standards.

(5) The abrasion of the sample was tested using an abrasion test machine according to GB9867-2008 standard.

(6) The slip resistance of the sample was tested using a slip resistance test machine according to TM 144 standard

\subsection{Plantar pressure test}

Plantar pressure test was performed using an insole plantar pressure test system.

\subsubsection{Selection of subjects}

In this study, tested were athletes wearing the test shoes with the sample sole, shoes purchased on the market with soles made of ethylene-vinyl acetate copolymer (EVA) foamed material (control shoes), and those with no shoes. In the BIIR, which was used for manufacturing the experimental shoes, the dosage of C5 was 10 phr, the tensile strength was $17.4 \mathrm{MPa}$, and the elongation at break of cells was $690 \%$, suggesting a good molecular structure. EVA foamed material, which was used for manufacturing the control shoes, was composed of ethylene and vinyl acetate, and its content was $14 \%-30 \%$; the shoes were ordinary brand shoes. The athletes selected were those who had done running exercise for more than one year, ran no less than $10 \mathrm{~km}$ every week, had no injury on the lower limbs in the last six months, and did no intense exercise within $48 \mathrm{~h}$ before the test.

\subsubsection{Partition of plantar pressure}

The human plantar was divided into different parts during pressure test. The pressure data were recorded. The plantar pressure partition is shown in Fig. 1. 


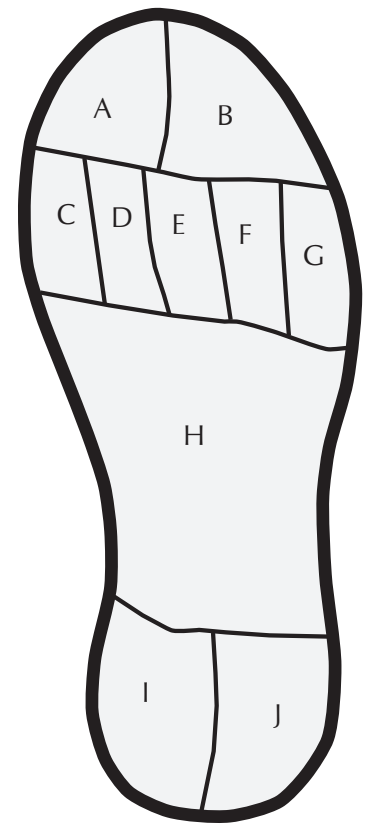

Fig. 1 - Partition of plantar pressure

A stands for the first phalanx, B stands for the second to fifth phalanx, C, D, E, F and G stand for the first, second, third, fourth, and fifth metatarsal bone, respectively, $\mathrm{H}$ stands for arch, I stands for the inner side of heel, and J stands for the outer side of heel.

\subsubsection{Test process}

The plantar pressure data of the right foot were collected, and the sampling frequency was set as $100 \mathrm{~Hz}$. Before the test, the athletes wore test equipment and plantar pressure data acquisition box; system zero adjustment was performed. Moreover, the athletes were asked to be familiar with the sports platform.
After preparation, the athletes were asked to run on the sports platform at a speed of $3 \mathrm{~m} \mathrm{~s}^{-1}$. After $20 \mathrm{~s}$ of uniform motion, the plantar pressure data of the athletes were collected. The data for the athletes wearing the test shoes, control shoes, and no shoes were all recorded. At the end, the athletes walked on the sports platform at a speed of $1.5 \mathrm{~m} \mathrm{~s}^{-1}$, and the other conditions remained the same; the pressure data were collected.

\section{Results and discussion}

\subsection{Vulcanization and Mooney properties}

The vulcanization degree of the manufactured samples was different due to different dosage of $\mathrm{C} 5$. The vulcanization parameters of the sample are shown in Table 1.

The experimental results are shown in Table 1. With the increase in dosage of $\mathrm{C} 5$, the initial torque and maximum torque of the sample and torque difference decreased gradually, and the scorch time and optimum cure time extended. This indicated that the addition of C5 could reduce the crosslinking of rubber and viscosity of rubber compound; moreover, the gap between molecule segments became larger, which led to the decrease in concentration of vulcanizing agent and accelerator, and extended the curing time. With the increase in curing time, the initial torque and maximum torque decreased steadily, suggesting that the curing time had no influence on vulcanization flatness.

With the increase in C5 dosage, the Mooney viscosity of the sole material greatly decreased firstly, and then tended to be stable, as shown in Fig. 1. As C5 resin acted as a softener in the process of sulphuration, the molecular weight and torque of the material decreased, leading to the decrease in Mooney viscosity. ${ }^{11}$ When the dosage of $\mathrm{C} 5$ resin became saturated, it acted as filler in rubber compound and would not reduce the viscosity of the material. Therefore, when the dosage of C5 exceeded 10 phr, the Mooney viscosity tended to be stable.

Table 1 - Vulcanization parameters of the material

\begin{tabular}{c|c|c|c|c|c}
\hline $\begin{array}{c}\text { Dosage of C5 } \\
\text { / phr }\end{array}$ & $\begin{array}{c}\text { Scorch time/ } \\
\text { min }\end{array}$ & $\begin{array}{c}\text { Optimum cure } \\
\text { time/min }\end{array}$ & $\begin{array}{c}\text { Initial torque/ } \\
\mathrm{dN} \mathrm{m}\end{array}$ & $\begin{array}{c}\text { Maximum } \\
\text { torque/dN m }\end{array}$ & $\begin{array}{c}\text { Torque } \\
\text { difference/ } \\
\mathrm{dN} \mathrm{m}\end{array}$ \\
\hline 0 & 2.5 & 5.9 & 9.1 & 32.6 & 23.4 \\
5 & 2.1 & 5.7 & 7.0 & 27.4 & 20.2 \\
10 & 2.9 & 5.9 & 6.6 & 22.4 & 14.5 \\
15 & 3.3 & 6.6 & 6.4 & 20.2 & 12.7 \\
25 & 2.6 & 6.8 & 5.1 & 17.4 & 10.6 \\
\hline
\end{tabular}




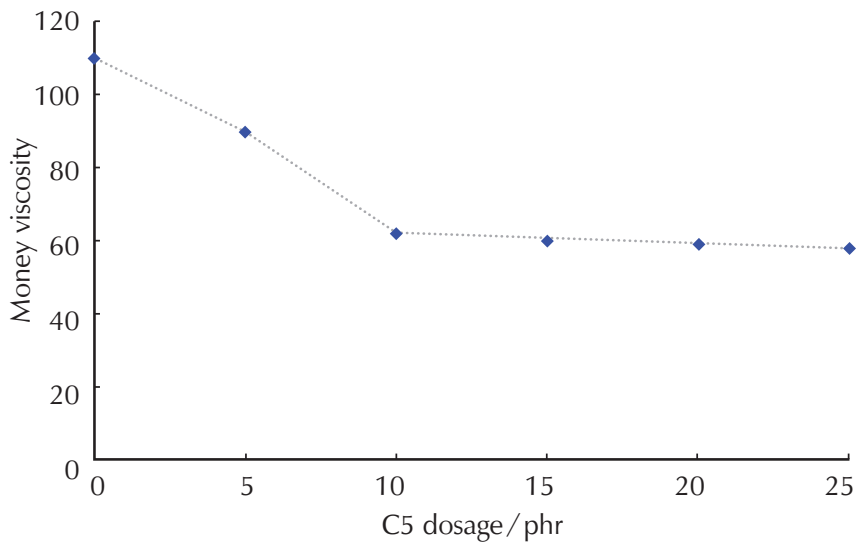

Fig. 2 - Influence of C5 dosage on the Mooney viscosity

\subsection{Analysis on slip resistance and mechanical properties}

Table 2 suggests that the wet slip resistance of the forefoot, smooth and heal increased with the increase in C5 dosage, indicating that the addition of C5 could significantly improve the wet slip resistance of the materials. As to dry slip resistance coefficient, the slip resistance coefficients of the forefoot, smooth and heal changed slightly, suggesting that the addition of $\mathrm{C} 5$ had little influence on the wet slip resistance of the material.

With the increase in C5 dosage, DIN abrasion had little changes in the earlier stage, ${ }^{12}$ but showed a sharp increase when the dosage of $\mathrm{C} 5$ exceeded 15 phr. This was because the short chain of $\mathrm{C} 5$, which combined with the macromolecule segment, reduced the degree of freedom of rubber, improved the temperature of transforming to vitrification, and increased the crosslinking between the rubbers. ${ }^{13}$ When the dosage of $\mathrm{C} 5$ was no more than $15 \mathrm{phr}$, the influence on the DIN abrasion of the material was low.

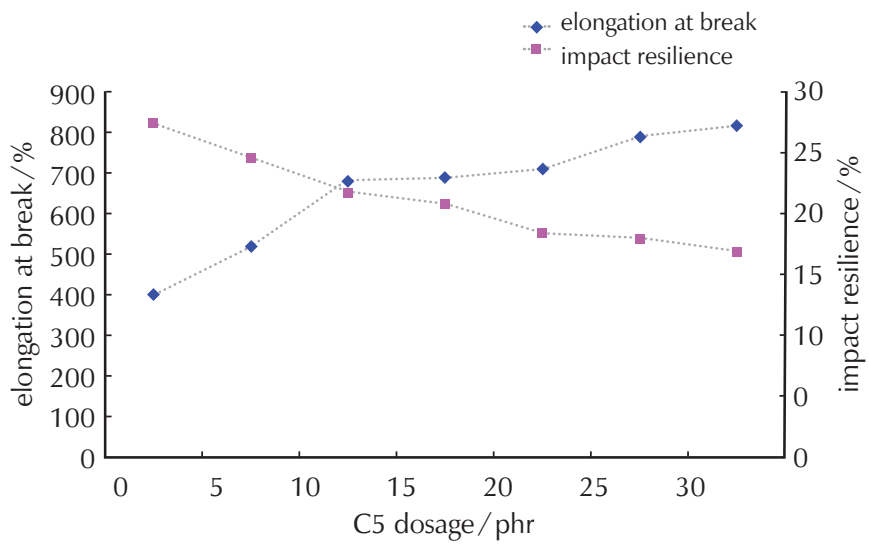

Fig. 3 - Influence of dosage of C5 on the elongation at break and impact resilience

Table 2 demonstrates that the tensile strength of the material increased firstly and then decreased, and the elongation at break improved constantly with the increase in C5 dosage. This was because the filler and compounding agents gradually dispersed with the increase in C5 dosage, leading to the interfacial compatibility of the material and the improvement of bonding strength between the rubbers. When the dosage of C5 exceeded 15 phr, the adhesion between the two rubbers decreased, and the interaction between the filler and the matrix weakened, leading to the decrease in tensile strength.

This was because the addition of C5 improved the action capacity of molecular segment, the relative slippage between molecular segment and the activity of crosslinked network, leading to the enhancement of elongation at break.

It could be concluded from Table 2 and Fig. 1 that the addition of $\mathrm{C} 5$ changed the crosslinking density and torque of the material, and consequently the hardness and impact resilience decreased with the increase in C5 dosage. The decrease in impact resilience suggested the enhancement of shock resistance of the material.

Table 2 - Influence of C5 dosage on the slip resistance coefficient and mechanical properties

\begin{tabular}{|c|c|c|c|c|c|c|c|c|c|}
\hline \multirow{2}{*}{$\begin{array}{c}\text { C5 dosage } \\
\text { / phr }\end{array}$} & \multirow{2}{*}{$\begin{array}{l}\text { Tensile } \\
\text { strength / } \\
\mathrm{MPa}\end{array}$} & \multirow{2}{*}{$\begin{array}{l}\text { Hardness } \\
\text { (Shore A) }\end{array}$} & \multirow{2}{*}{$\begin{array}{c}\text { DIN } \\
\text { abrasion / } \\
\mathrm{mm}^{3}\end{array}$} & \multicolumn{3}{|c|}{ Slip resistance coefficient (dry) } & \multicolumn{3}{|c|}{ Slip resistance coefficient (wet) } \\
\hline & & & & forefoot & smooth & heel & forefoot & smooth & heel \\
\hline 0 & 14 & 71.2 & 97.2 & 1.14 & 0.96 & 0.79 & 0.47 & 0.46 & 0.43 \\
\hline 5 & 16.2 & 65.8 & 99.7 & 1.09 & 1.07 & 0.87 & 0.49 & 0.52 & 0.46 \\
\hline 10 & 17.4 & 62.3 & 99.5 & 1.1 & 1.06 & 0.83 & 0.5 & 0.55 & 0.47 \\
\hline 15 & 17.5 & 59.7 & 100.1 & 1.14 & 1.08 & 0.79 & 0.53 & 0.6 & 0.5 \\
\hline 20 & 14.3 & 53.7 & 112.3 & 1.03 & 1.07 & 0.85 & 0.55 & 0.67 & 0.52 \\
\hline
\end{tabular}




\subsection{Pressure test on rubber sole, naked feet, and ordinary sole}

The peak pressure is shown in Fig. 4.
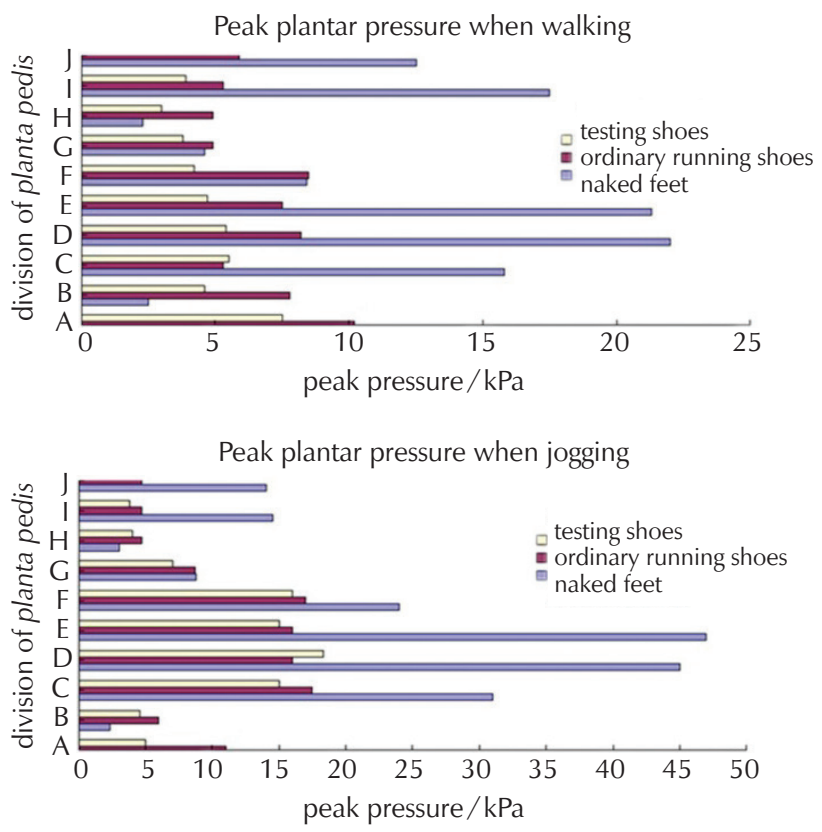

Fig. 4 - Peak plantar pressure when walking and jogging

Fig. 4 demonstrates that the peak plantar pressure of feet wearing shoes when walking was obviously lower than that of naked feet; the position with high plantar pressure previously had significantly pressure. It could be concluded that by wearing the running shoes excessive pressure and generation of local pain could be avoided, and comfort during walking improved.

The pressure on the feet wearing the test shoes was distributed more evenly compared to ordinary shoes. Except the first metatarsal bone whose pressure had slightly increases, the pressure of the other parts had remarkably reduced. This indicated that the sole, which was made of BIIR and $B R$, could more effectively reduce plantar pressure and improve comfort.

\section{Conclusion}

This study investigated the properties of $B I I R$ and $B R$, and developed the sole of running shoes with BIIR, BR, and C5 petroleum resin. Experiments were carried out to prove that the rubber could improve the strength, hardness, tensile strength, and abrasion resistance of running shoes soles. The exercise test suggested that the shoes could effectively reduce plantar pressure and enhance comfort. This work provides a reference for the manufacture of running shoes with rubber.

\author{
List of abbreviations and symbols \\ BIIR - brominated isobutylene-isoprene rubber \\ BR - butadiene rubber \\ EVA - ethylene-vinyl acetate \\ phr - parts per hundred rubber
}

\section{References \\ Literatura}

1. K. Pyo, J. Choi, J. Lee, C. Park, Improvement of Frictional Property of BR/CIIR Composite Rubber for Shoes Outsole, Polym. Korea 37 (3) (2013) 255-261, doi: https:// doi.org/10.7317/pk.2013.37.3.255.

2. Y. Wang, W. Y. Zhou, L. Li, A. M. Zhang, SEBS modified reclaimed rubber microcellular foaming material as the sole of the shoe, Polym. Mater. Sci. Eng. 26 (12) (2010) 148-151, url: http://caod.oriprobe.com/articles/25909767/ SEBS_Modified_Reclaimed_Rubber_Microcellular_Foami. htm.

3. Y. Zhang, S. X. Li, W. L. Guo, Z. W. Deng, The Effects of Bromination Condition on the Microstructure of Brominated Butyl Rubber, J. Petrochem. Univ. 23 (1) (2010) 27-29, url: http://en.cnki.com.cn/Article_en/CJFDTotal-SYHX201001007.htm.

4. X. Yang, Y. Zhang, Y. Xu, S. Gao, S. Guo, Effect of octadecylamine modified graphene on thermal stability, mechanical properties and gas barrier properties of brominated butyl rubber, Macromol. Res. 25 (3) (2017) 270-275, doi: https://doi.org/10.1007/s13233-017-5035-7.

5. C. A. D. Silva, H. Budde, M. Menzel, U. Wendler, M. Bartke, M. Weydert, M. Beiner, Self-assembled structure and relaxation dynamics of diblock copolymers made of polybutadiene and styrene/butadiene rubber, RSC Adv. 6 (56) (2016) 50460-50470, doi: https://doi.org/10.1039/ C6RA06786G.

6. S. S. Choi, K. H. Chung, C. Nah, Improvement of properties of silica-filled styrene-butadiene rubber (SBR) compounds using acrylonitrile-styrene-butadiene rubber (NSBR), Polym. Adv. Technol. 14 (8) (2010) 557-564, doi: https://doi.org/10.1002/pat.367.

7. J. Liang, S. Chang, N. Feng, Effect of C5 petroleum resin content on damping behavior, morphology, and mechanical properties of BIIR/BR vulcanizates, J. Appl. Polym. Sci. 130 (1) (2013) 510-515, doi: https://doi.org/10.1002/ app.39202.

8. N. J. Mills, Chapter 13-Running shoe case study, in Polymer Foams Handbook, 2007, pp. 307-327, doi: https:// doi.org/10.1016/B978-075068069-1/50014-3.

9. K. Harano, The Athletic Shoes, Nippon Gomu Kyokaishi 83 (5) (2010) 133-137, doi: https://doi.org/10.2324/ gomu.83.133.

10. A. F. Plante, C. Peltre, J. Chan, T. Baumgartl, P. Erskine, M. Apesteguía, I. Virto, Green Carbon, Black Carbon, White Carbon: Simultaneous Differentiation Between Soil Organic Matter, Pyrogenic Carbon and Carbonates Using Thermal Analysis Techniques, AGU Fall Meeting, AGU 
Fall Meeting Abstracts, 2014, url: http://adsabs.harvard. edu/abs/2014AGUFM.B31L..01P.

11. H. Nouailhas, C. Aouf, C. L. Guerneve, S. Caillol, B. Boutevin, H. Fulceand, Synthesis and properties of biobased epoxy resins. Part 1. Glycidylation of flavonoids by epichlorohydrin, J. Polym. Sci. Part A Polym. Chem. 49 (10) (2011) 2261-2270, doi: https://doi.org/10.1002/ pola.24659.

12. A. M. Rashad, E. D. H. Seleem, A. F. Shaheen, Effect of
Silica Fume and Slag on Compressive Strength and Abrasion Resistance of HVFA Concrete, Int. J. Concrete Struct. Mater. 8 (1) (2014) 69-81, doi: https://doi.org/10.1007/ s40069-013-0051-2.

13. K. Pal, R. Rajasekar, D. J. Kang, Z. X. Zhang, S. K. Pal, C. K. Das, J. K. Kim, Effect of fillers on natural rubber/high styrene rubber blends with nano silica: Morphology and wear, Mater. Design 31 (2) (2010) 677-686, doi: https:// doi.org/10.1016/j.matdes.2009.08.014.

\section{SAŽETAK \\ Djelovanje tenisica s abrazivno otpornim gumenim potplatima na vježbanje \\ Bo Wang}

S razvojem industrijalizacije guma se zbog svojih povoljnih svojstava sve više upotrebljava u proizvodnji sportske opreme. Tijekom ovog istraživanja C5-naftna smola dodana je bromizobuten/ izopropilenskom kaučuku (BIIR) i butadienskom kaučuku (BR) pri proizvodnji potplata tenisice. Djelovanje tenisice s abrazivno otopornim gumenim potplatom na kretanje ispitivan je analizom otpornosti na klizanje i otpornosti na abraziju tenisice te provedbom biomehaničkog ispitivanja na golim stopalima i stopalima s cipelama. Rezultati su pokazali da gumeni potplat ima povoljna svojstva otpornosti na klizanje i mehanička svojstva kao što su istezanje, otpornost na abraziju i tvrdoću. U usporedbi s golim stopalima, vršni intenzitet tlaka cijelog koraka, kada su noge nosile novorazvijene cipele, bio je znatno niži nego kada su noge nosile obične cipele.

\section{Ključne riječi}

Gumene cipele, analiza performansi gumenog potplata, biomehanika

College of Physical Education,

Sichuan Normal University, Chengdu

Sichuan 610 101, Kina
Stručni rad

Prispjelo 14. lipnja 2017 Prihvaćeno 1. rujna 2017. 